\title{
The Evolution of Biblical Hebrew Linguistics in South Africa: The Last 60 Years ${ }^{1}$
}

\author{
Jacobus A. NAUdé ANd Cynthia L. Miller-NaUdé (University OF \\ THE FREE STATE)
}

\begin{abstract}
In this article we survey the evolution of Biblical Hebrew linguistics in South Africa during the last six decades-its dependence upon and contribution to European and American developments and its distinct contributions to the field. Three eras can be distinguished. In the first era, the study of Biblical Hebrew in South Africa was primarily philological in nature and both teaching grammars and research focused mainly on grammar and specifically the writing system, word formation and vocabulary. In the second era, the study of Biblical Hebrew in South Africa was heavily influenced by the new developments in Europe and the USA concerning linguistics and especially its influence in the fields of Biblical Hebrew syntax and discourse analysis. In the third era, Biblical Hebrew linguistics in South Africa contributes to the development of the field by taking into account the complexity of Biblical Hebrew as a language. The description and explanation of the nature of the verbless clause, and specifically the tripartite and left dislocated verbless clause in Biblical Hebrew are discussed as a case in point both of the development of linguistics and Biblical Hebrew in South Africa and of the impact of linguistics on exegesis and Bible translation.
\end{abstract}

* Submitted: 23/09/2017; peer-reviewed: 17/10/2017; accepted: 01/03/2018. Jacobus A. Naudé and Cynthia L. Miller-Naudé, "The Evolution of Biblical Hebrew Linguistics in South Africa: The Last 60 Years," OTE 31 no. 1 (2018): 12-41. DOI: https://doi.org/10.17159/2312-3621/2018/v31n1a3

It is a pleasure to dedicate this article to our friend and colleague, Prof Izak JJ Spangenberg, for his appreciation of Hebrew linguistics in Old Testament exegesis, on the occasion of his retirement from UNISA. A shorter version of this paper was presented at the 2017 annual conference of the Old Testament Society of South Africa, which celebrated the 60th anniversary of the society. This work is based on research supported in part by the National Research Foundation of South Africa (Jacobus A. Naudé UID 85902 and Cynthia L. Miller-Naudé UID 95926). The grant-holders acknowledge that opinions, findings and conclusions or recommendations expressed in any publication generated by the NRF supported research are those of the authors, and that the NRF accepts no liability whatsoever in this regard. 
KEYWORDS: Biblical Hebrew linguistics; Biblical Hebrew language; historical linguistics; linguistics; philology; verbless clause; dislocated verbless clause; tripartite verbless clause.

\section{A INTRODUCTION}

Linguistics as a discipline is the science of language which takes as its object universal aspects of language structure and function, as well as the description and comparison of individual languages. Linguists use their knowledge of a specific language to enhance their understanding of language as such; conversely, they apply that general understanding to the study of a specific language. When a specific language is the object of study, the term linguistics is qualified by the name of that specific language; in this case Biblical Hebrew linguistics. Biblical Hebrew linguistics addresses the study of Biblical Hebrew grammar by using well-articulated linguistic methods and applying general linguistic theories to particular Biblical Hebrew constructions or corpuses. ${ }^{2}$

In this article we survey the evolution of Biblical Hebrew linguistics in South Africa during the last six decades - its dependence upon and contribution to European and American developments and its distinct contributions to the field. The focus is on the trends of the interaction and not a historiography of Biblical Hebrew linguistics in general or in South Africa in particular. The methodology to determine the impact will be qualitative rather than quantitative - the focus is on what is published and referenced or quoted with emphasis on features of the sentence in Biblical Hebrew. A survey of the verbless clause will be the case in point in this regard. The impact of the interaction is determined by what is published in Europe and America concerning the verbless clause on the one hand and what is published in South Africa on the other hand as well as the quotations and references to each other. Other aspects of the application of linguistics to Biblical Hebrew, such as applied linguistics ${ }^{3}$ and corpus linguistics, fall outside the scope of this article.

2 We follow scholarly convention in using the term "Biblical Hebrew" to refer to the language of ancient Israel as it is preserved in the HB, although other names have been used. See Christo H. J. van der Merwe, Jacobus A. Naudé, and Jan H. Kroeze, Biblical Hebrew Reference Grammar, 2nd ed., BibLH 3 (London: Bloomsbury, 2017 [1st ed. Sheffield: Sheffield Academic Press, 1999]), 1-6. For the issues involved in the linguistic analysis of ancient Hebrew and the difficulties in reconstructing its linguistic system, see Cynthia L. Miller, "Methodological Issues in Reconstructing a Language System from Epigraphic Fragments," in The Future of Biblical Archaeology: Reassessing Methods and Assumptions, ed. James K. Hoffmeier and Alan Millard (Grand Rapids: Eerdmans, 2004), 281-305.

3 Applied linguistics in the South African context includes language pedagogy, translation studies, interpreting, language editing, document design, lexicography, terminology and human language technology. 
The article is organised as follows. Firstly, we deal with the emergence and nature of linguistics as a new discipline. Secondly, we deal with the impact of linguistics on the description of Hebrew in Europe and America as well as in South Africa. Lastly, the description and explanation of the nature of the verbless clause, and specifically the tripartite verbless clause and left dislocated verbless clause in Biblical Hebrew are discussed as examples both of the development of linguistics and Biblical Hebrew in South Africa and of the impact of linguistics on exegesis.

\section{B EMERGENCE OF LINGUISTICS AS A NEW DISCIPLINE}

The term "linguistics" refers to a new discipline in the study of language which was developing in the middle of the nineteenth century and which needed to be differentiated from the approach of modern philology which achieved unprecedented institutional dominance in the nineteenth-century European university. ${ }^{4}$ Modern philology covered inter alia textual philology, theories of the origin and nature of language, the comparative study of language and the historical evolution of languages and language families. ${ }^{5}$

In the late nineteenth century and early twentieth century, scholars began to downscale the scope of philology and a process of fragmentation and reformulation started. It was not just institutional but also intellectual fragmentation, which has been described as, on the one hand, theory without practice, namely literary studies, and on the other hand, as practice without theory, namely philology. ${ }^{6}$ The grand nineteenth century "mansion" of philology was soon to see one of its "two principal divisions" expropriated by the new science of linguistics. The other was carved up and seized by national literary histories, comparative literature, and literary criticism and theory. ${ }^{7}$ Philology vanished.

The independence of linguistics as a discipline was first declared in 1916 by Ferdinand de Saussure and then repeated by Otto Jespersen (1860-1943) in 1922. ${ }^{8}$ Distinctive emphases (for example, claims of a scientific character) set linguistics as a new discipline apart from modern philology. Although

4 Sheldon Pollock, "Introduction," in World Philology, ed. Sheldon Pollock, Benjamin A. Elman, and Ku-ming Kevin Chang (Cambridge, MA: Harvard University Press, 2015), 2.

5 James Turner, Philology: The Forgotten Origins of the Modern Humanities (Princeton: Princeton University Press, 2014), 123-380.

6 Pollock, "Introduction," 3.

7 Pollock, "Introduction," 8.

8 Geoffrey Finch, Key Concepts in Language and Linguistics, 2nd ed. (New York: Palgrave MacMillan, 2005), 3-7; Robert H. Robins, A Short History of Linguistics, 4th ed. (London: Longmans, 1997), 199, 200, 206; see also John Lyons, Introduction to Theoretical Linguistics (Cambridge: Cambridge University Press, 1968), 4, 21, 38. 
approaches, theories and methodologies for studying language have changed since its inception as a discipline in the early twentieth century, the focus of linguistics as a discipline has remained constant, that is the systematic, scientific study of the lingual properties of natural (i.e. human) language. ${ }^{9}$ The method of linguistic enquiry is empirical and proceeds by observation, description and explanation of language use. ${ }^{10}$ Explanations of language use are the stage at which linguists endeavour to establish the underlying rules which speakers internalise to construct and use sounds, words, sentences as well as the way meanings are assigned to these units of a language in order to communicate. ${ }^{11}$ Each one of these aspects of language is the focus of a sub-discipline of linguistics, namely, phonology, morphology, syntax, semantics. ${ }^{12}$

Structural linguistics in Europe, which began with De Saussure, can be summed up in three dichotomies, namely synchronic versus diachronic, langue (language system) versus parole (language behaviour), and form (structure or pattern) versus substance. ${ }^{13}$ In American structuralism, Franz Boas (died 1942) and his student Edward Sapir (died 1939) were attracted to the relationship between language and thought, but it was Benjamin Lee Whorf who formulated the thesis that language determines perception and thought. ${ }^{14}$ For thirty years since 1933 Leonard Bloomfield dominated the field with a behaviouristic approach to the study of language. ${ }^{15}$ In the mid-1950s two versions of transformational grammar were put forward - the first by Zellig S. Harris and the second by Noam Chomsky, his student. ${ }^{16}$ Chomsky adopted what he called a mentalistic theory of language, by which the linguist should be concerned with the speaker's linguistic competence and not his performance. Chomsky's generative linguistics has been the dominant theory of linguistics in the US for more than fifty years. Noam Chomsky began generative grammar as a rule system but changed it to a principle and parameter approach in the late 1970s. The Principles and Parameters Model (or, Government and Binding Theory) is a syntactic model of human language centred on universal principles argued to be common to all languages, and specific, distinct sets of parameters whose values are fixed in one of a limited number of ways to derive the particular grammar of

9 Rudolf P. Botha, The Conduct of Linguistic Inquiry (The Hague: Mouton Publishers, 1981), 437.

10 Botha, Conduct, 24-431.

11 Botha, Conduct, 184-238.

12 Finch, Key Concepts, 32-177, 179.

13 Ferdinand de Saussure, Course in General Linguistics (New York: Philosophical Library, 1959).

14 Benjamin L. Whorf, Language, Thought and Reality: Selected Papers (New York: Wiley, 1956).

15 Leonard Bloomfield, Language (New York: Holt, Rinehart and Winston, 1933).

16 Zellig S. Harris, Structural Linguistics (Chicago: Chicago University Press, 1961); Noam Chomsky, Syntactic Structures (The Hague: Mouton, 1957). 
a specific language. In the early 1990s the fact that language may be designed economically is suggested by various kinds of minimalist considerations and this constituted the next development in generative grammar, the Minimalist Programme. ${ }^{17}$ Among the rival schools to generative linguistics are tagmemics developed by the US linguist, Kenneth Pike, for analysing previously unrecorded languages; ${ }^{18}$ stratificational grammar developed by the US linguist, Sydney Lamb as a radical modification of post-Bloomfieldian linguistics; ${ }^{19}$ functional grammar developed by Simon Dik; ${ }^{20}$ systemic-functional grammar developed by Michael Halliday in England as a more systemic and comprehensive theory of the structure of language; ${ }^{21}$ and cognitive linguistics, associated with inter alia George Lakoff and Mark Johnson, as an explanation of grammatical patterns by general cognitive structures, processes, and contents. ${ }^{22}$ Functional Grammar is geared to the study of language as communication. It sees meaning in the linguistic choices of the speaker/writer and systematically relates these choices to a wider sociocultural framework. Further developments concern sociolinguistic approaches which moved beyond formal linguistics to address communicative competence, discourse and conversational analysis and the text as a linguistic unit. It was the Danish linguist Hjelmslev, who foresaw the study of texts as the objects of linguistic inquiry, the handling of the standards of textuality and types of cohesion. ${ }^{23}$ Complexity theory has emerged in the recent

17 Jacobus A. Naudé, review of On Nature and Language, by Noam Chomsky, SALALS 24/1 (2006): 125-27.

18 Kenneth L. Pike, Language in Relation to a Unified Theory of the Structure of Human Behaviour, 2nd rev. ed. (The Hague: Mouton, 1967).

19 Sydney M. Lamb, Outline of Stratificational Grammar (Washington, D.C.: Georgetown University Press, 1966).

20 Simon C. Dik, Functional Grammar (London: Academic Press, 1978); Simon C. Dik, The Theory of Functional Grammar (Dordrecht: Foris, 1989).

21 Michael A. K. Halliday, An Introduction to Functional Grammar (London: Arnold, 1994); Michael A. K. Halliday and Christian M. I. M. Matthiessen, An Introduction to Functional Grammar, 3rd ed. (London: Arnold, 2004).

22 George Lakoff and Mark Johnson, Metaphors We Live By (Chicago: University of Chicago Press, 1980); George Lakoff and Mark Turner, More than Cool Reason (Chicago: University of Chicago Press, 1989).

23 Louis Hjelmslev, Principes de Grammaire Générale (Copenhague: Høst \& Søn, 1928), Roman Jakobson, Language in Literature (Cambridge, MA: The Belknap Press of Harvard University Press, 1987). 
past as a new paradigm of doing not only applied linguistics, but also of gaining a new perspective on language in terms of a complex systems approach. ${ }^{24}$

In the next section we survey the general trends in applying linguistics to Biblical Hebrew as background for the study of Biblical Hebrew linguistics in South Africa.

\section{LINGUISTICS AND THE DESCRIPTION OF BIBLICAL HEBREW \\ $1 \quad$ General trends}

Early evidence for the study of Biblical Hebrew grammar stems from the medieval Jewish grammarians, for example Sa'adyah Gaon and David Qimhi, whose grammatical works were written in Arabic. ${ }^{25}$ During the Renaissance the study of Biblical Hebrew philology flourished, especially through the contributions of Christian scholars like Johannes Reuchlin (1455-1522), who published his grammar De rudimentis hebraicis in 1506 and a treatise on Hebrew grammar and on the cantillations of the Bible, De accentibus et orthographia linguae hebraicae, in 1518, as well as through the contribution of the Christian Hebraists in Basel, for example Conrad Pellican, Wolfgang Fabricus Capito, and Sebastian Münster. ${ }^{26}$ Their grammatical works were written in Latin. The Jewish scholar Elias Levita wrote several grammars and taught Hebrew to Christians in Rome. ${ }^{27}$

24 Diane Larsen-Freeman and Lynne Cameron, Complex Systems and Applied Linguistics (Oxford: Oxford University Press, 2008); Nick C. Ellis and Diane LarsenFreeman, eds., Language as a Complex Adaptive System (Ann Arbor, MI: Language Learning Research Club, 2009); Talmy Givón, The Genesis of Syntactic Complexity: Diachrony, Ontogeny, Neuro-cognition, Evolution (Philadelphia: John Benjamins, 2009); Geoffrey Sampson, David Gil, and Peter Trudgill, Language Complexity as an Evolving Variable (Oxford: Oxford University Press, 2009).

25 William Chomsky, Hebrew: The Eternal Language (Philadelphia: The Jewish Publication Society of America, 1957), 117-31; Robert Brody, Sa'adyah Gaon (Oxford: The Littman Library of Jewish Civilization, 2013), 79-96; William Chomsky, David Kimhi's Hebrew Grammar (Mikhlol) (New York: Bloch Publishing Company, 1952); Mordechai Cohen, "The Qimhi Family" in The Middle Ages, part 2 of From the Beginnings to the Middle Ages, vol. 1 of Hebrew Bible/Old Testament: The History of Its Interpretation, ed. Magne Sæbø (Göttingen: Vandenhoeck \& Ruprecht, 2000), 388415.

26 Sophie Kessler-Mesguish, "Early Christian Hebraists," in From the Renaissance to the Enlightenment, vol. 2 of Hebrew Bible/Old Testament: The History of Its Interpretation, ed. Magne Sæbø (Göttingen: Vandenhoeck \& Ruprecht, 2008), 254-72.

27 Kessler-Mesguish, "Early Christian,” 272-75. 
Philological investigations of Hebrew have yielded important results. ${ }^{28}$ The authoritative Biblical Hebrew grammar of Wilhelm Gesenius (1786-1842), which appeared for the first time in 1813 and which has been followed by 28 subsequent editions, dominated the scene and provides evidence of the nature of Biblical Hebrew scholarship during the nineteenth-century. ${ }^{29}$ Wilhelm Gesenius published twelve more editions, Emil Rödiger (1801-1874) took care of the fourteenth to twenty-first editions (1845-1872), while the twenty-second to the twenty-eight editions (1878-1909) were produced by Emil Kautzsch (18411910) and in 1910 Cowley produced an English version. ${ }^{30}$ In 1929 Bergsträsser published the 29th edition of Gesenius' grammar, which incorporated data from Greek and Latin inscriptions, and the Babylonian and Palestinian vocalization systems. ${ }^{31}$ These revisions changed the profile of what was meant to be a modest presentation for learners into a more ambitious research grammar updated in light of contemporary work on Comparative Semitics and enriched by references to the secondary literature. ${ }^{32}$ One feature of Gesenius' grammar is its descriptive model, which is based on universal logical categories mostly derived from Latin grammar; the other feature is the dethronement of Hebrew as the primordial Semitic language and demonstration of the place of Hebrew among the languages of the ANE. ${ }^{33}$ When Kautzsch took over the revision, he based some of the syntactic descriptions on word order, for example a verbless clause became a clause that begins with an independent subject like a noun or a personal pronoun even when a verb later follows, while only verb-initial clauses were viewed as verbal clauses. ${ }^{34}$ It was only in the twenty-fifth edition (1889) that Kautzsch decided that a sentence type is dependent on the nature of the predicate: a nominal clause has a nominal predicate, a verbal clause contains a finite verb. ${ }^{35}$

A dissimilar grammar to the one of Gesenius was published by Heinrich Ewald (1803-1875) - the first edition of his grammar in 1827 and the eighth and last edition in $1870 .{ }^{36} \mathrm{He}$ did not confine himself to a mere description of

28 Turner, Philology, 210-29, 363, 367.

29 GKC, iii-vii.

30 GKC, v.

31 Gotthelf Bergsträsser, Hebräische Grammatik: Mit Benutzung der von E. Kautzsch bearbeiten 28. Auflage von Wilhelm Gesenius' hebräischer Grammatik (Hildesheim: Georg Olms Verlag, repr. 1962).

32 Holger Gzella, "Expansion of the Linguistic Context of the Hebrew Bible/Old Testament: Hebrew among the Languages of the Ancient Near East," in The Nineteenth Century - a Century of Modernism and Historicism, part 1 of From Modernism to PostModernism (The Nineteenth and Twentieth Centuries), vol. 3 of Hebrew Bible/Old Testament: The History of Its Interpretation, ed. Magne Sæb $\varnothing$ (Göttingen: Vandenhoeck \& Ruprecht, 2000), 151.

33 Gzella, "Expansion," 134-67.

34 Gzella, "Expansion," 152.

35 Gzella, "Expansion," 152.

36 Gzella, "Expansion," 156. 
linguistic facts, but wanted to uncover the driving forces shaping language as an organic system and its philosophy, which led to a new understanding of the verbal system. ${ }^{37}$

The comprehensive grammar of Eduard König (1846-1936), which appeared in three volumes between 1881 and 1897, still counts as the most important full description of Biblical Hebrew syntax. ${ }^{38}$ The study of the Hebrew in the late books of the Bible begun with Arno Kropat in his 1909 work on the syntax of Chronicles. ${ }^{39}$

The historical-comparative philology led to the grammars of Carl Brockelmann, published between 1908 and 1913, and of Hans Bauer (18781937) and Pontus Leander (1872-1935), published in $1922 .{ }^{40}$ The last-mentioned grammar reconstructed Hebrew as a mixed language composed of an older stratum of Canaanite spoken by the indigenous inhabitants of Canaan and a younger linguistic stratum that was brought into the area by later immigrants. ${ }^{41}$ The focus was on the study of phonology and morphology of language, with the result that these grammars hardly have any description of Biblical Hebrew syntax. An exception is Brockelmann's syntax of 1956 which explains most syntactic constructions in terms of psychological considerations. ${ }^{42}$ The first grammar to incorporate material from Ugaritic, the Dead Sea Scrolls and Ben Sira was composed between 1966 and 1972 by Rudolf Meyer (1909-1991). ${ }^{43}$

Although linguistics as a new discipline hosts new theories of language, it did not have an immediate influence on Biblical Hebrew grammar. It was only

37 Gzella, "Expansion," 157.

38 Friedrich E. König, Historisch-kritisches Lehrgebäude der hebräischen Sprache, 3 vols. (Hildesheim: Georg Olm Verlag, repr. 1979); Gzella, "Expansion,” 164.

39 Arno Kropat, Die Syntax des Autors der Chronik verglichen mit der seiner Quellen: Ein Beitrag zur historischen Syntax des Hebräischen, BZAW 16 (Giessen: Alfred Töpelmann, 1909).

40 Carl Brockelmann, Grundriss der vergleichenden Grammatik der semitischen Sprachen, 2 vols. (Hildesheim: Georg Olms Verlag, repr. 1966); Hans Bauer and Pontus Leander, Historische Grammatik der Hebräischen Sprache des Alten Testaments (Halle: Verlag von Max Niemeyer, 1922); Bergsträsser, Hebräische Grammatik, Gzella, "Expansion," 163.

41 Steven E. Fassberg, "The Linguistic Context of Biblical Hebrew and Aramaic in the Framework of Semitic Philology, Including Semitic Epigraphy," in The Twentieth Century - From Modernism to Post-Modernism, part 2 of From Modernism to PostModernism (The Nineteenth and Twentieth Centuries), vol. 3 of Hebrew Bible/Old Testament: The History of Its Interpretation, ed. Magne Sæb $\varnothing$ (Göttingen: Vandenhoeck \& Ruprecht, 2015), 56.

42 Carl Brockelmann, Hebräische Syntax (Neukirchen-Vluyn: Neukirchener Verlag, 1956).

43 Rudolf Meyer, Hebräische Grammatik, SG, 3rd ed. (Berlin: De Gruyter, 19661972). 
in the 1970s that the study of Biblical Hebrew turned to syntax in works such as those by Francis Andersen on the sentence in Biblical Hebrew, Wolfgang Richter's three-volume grammar on ancient Hebrew and Walter Gross' analysis of left dislocation in Biblical Hebrew. ${ }^{44}$ In 1990 Bruce Waltke (1930- ) and Michael O'Connor (1950-2007) published a Biblical Hebrew syntax with descriptions based on traditional grammar as well as structuralist principles. ${ }^{45}$ Takamitsu Muraoka's grammar on Biblical Hebrew, which was published in 1991, is a revision of a French grammar on Biblical Hebrew published in 1923 by Paul Joüon. ${ }^{46}$ Muraoka adopted a structuralist approach in the categories and argumentation he used and incorporated the insights of modern grammarians. However, it is still in the form of a traditional grammar and explains some Biblical Hebrew syntactic constructions psychologically. The last two mentioned publications deal with the sentence as the largest unit of linguistic description and became standard reference works in Biblical Hebrew. In 1989 Robert E. Longacre introduced the application of discourse linguistics to Biblical Hebrew prose by providing a linguistic rationale for the macrostructure of texts. ${ }^{47}$ This idea of accounting of language structure beyond clause and sentence level is followed up in the publication of David Dawson, the edited work of Robert

44 Francis I. Andersen, The Sentence in Biblical Hebrew (New York: Mouton, 1974); Wolfgang Richter, Das Wort, vol. 1 of Grundlagen einer althebräischen Grammatik, ATSAT 8 (St. Ottilien: EOS Verlag, 1978); Wolfgang Richter, Die Wortfügung (Morphosyntax), vol. 2 of Grundlagen einer althebräischen Grammatik, ATSAT 10 (St. Ottilien: EOS Verlag, 1979); Wolfgang Richter, Der Satz, vol. 3 of Grundlagen einer althebräischen Grammatik, ATSAT 13 (St. Ottilien: EOS Verlag, 1980); Walter Gross, Die Pendenskonstruktion im biblischen Hebräisch, ATSAT 27 (St Ottilien: EOS Verlag, 1987); for discussion and overview of other developments, see Christo H. J. van der Merwe, "Recent Trends in the Linguistic Description of Old Hebrew," JNSL 15 (1989): 217-41.

45 Bruce K. Waltke and Michael O'Connor, Introduction to Biblical Hebrew Syntax (Winona Lake, IN: Eisenbrauns, 1990).

46 Paul Joüon, Grammaire de l'Hébreu biblique (Rome: Institut Biblique Pontifical, 1923 [1st ed.], 1947 [2nd ed.]); Paul Joüon and Takamitsu Muraoka, A Grammar of Biblical Hebrew (Rome: Pontifical Biblical Institute, 1991).

47 Robert E. Longacre, Joseph: A Story of Divine Providence: A Text Theoretical and Textlinguistic Analysis of Genesis 37 and 39-48 (Winona Lake, IN: Eisenbrauns, 1989); Cynthia L. Miller, review of A Study in Divine Providence: A Text Theoretical and Text-Linguistic Analysis of Genesis 37 and 39-48, by Joseph Longacre, JNES 56 (1997): 155-56. A second edition was produced in 2003. 
Bergen, both published in 1994, and in the book of Cynthia L. Miller on reported speech, published in $1996 .{ }^{48}$

In 1992, Walter Bodine edited a volume in which an introduction to the various disciplines of linguistics and their application to Biblical Hebrew is provided. ${ }^{49}$ Although the community of scholars studying Modern Hebrew from the generative perspective is fairly large,$^{50}$ only a few scholars pursue the study of Biblical Hebrew within the framework of generative grammar, ${ }^{51}$ for example Vincent DeCaen ${ }^{52}$ Robert Holmstedt ${ }^{53}$ and Joseph Malone. ${ }^{54}$ The functional grammar framework is utilised by Biblical Hebrew scholars like Randall Buth, ${ }^{55}$ Jean-Marc Heimerdinger, ${ }^{56}$ Michael Rosenbaum ${ }^{57}$ and Nicolai WintherNielsen. ${ }^{58}$ The empirical rigour provided by the various linguistic approaches encouraged many Biblical Hebrew scholars to use syntagmatic and paradigmatic

48 David A. Dawson, Text-Linguistics and Biblical Hebrew (Sheffield: Sheffield Academic Press, 1994); Robert B. Bergen, ed., Biblical Hebrew and Discourse Linguistics (Winona Lake, IN: Eisenbrauns, 1994); Cynthia L. Miller, The Representation of Speech in Biblical Hebrew Narrative: A Linguistic Analysis, HSM 55 (Atlanta: Scholars Press, 1996).

49 Walter R. Bodine, ed., Linguistics and Biblical Hebrew (Winona Lake, IN: Eisenbrauns, 1992).

50 Hagit Borer, "Generative Grammar and Hebrew," in Encyclopedia of Hebrew Language and Linguistics, ed. Geoffrey Khan (Leiden: Brill), 2:23-42.

51 Jacobus A. Naudé, "Government and Binding," in Encyclopedia of Hebrew Language and Linguistics, ed. Geoffrey Khan (Leiden: Brill), 2:72-76.

52 Vincent DeCaen, "Verbal and Verbless Clauses within Government-Binding Theory" in The Verbless Clause in Biblical Hebrew: Linguistic Approaches, ed. Cynthia L. Miller, LSAWS 1 (Winona Lake, IN: Eisenbrauns, 1999), 109-31.

53 Robert D. Holmstedt, The Relative Clause in Biblical Hebrew, LSAWS 10 (Winona Lake, IN: Eisenbrauns, 2016).

54 Joseph L. Malone, Tiberian Hebrew Phonology (Winona Lake, IN: Eisenbrauns, 1993).

55 Randall J. Buth, "Functional Grammar, Hebrew and Aramaic: An Integrated, Textlinguistic Approach to Syntax," in Discourse Analysis of Biblical Literature: What It Is and What It Offers, ed. Walter R. Bodine (Winona Lake, IN: Eisenbrauns, 1995), 77-102.

56 Jean-Marc Heimerdinger, Topic, Focus and Foreground in Ancient Hebrew Narrative, JSOT 295 (Sheffield: Sheffield Academic Press, 1999), 52-100.

57 Michael Rosenbaum, Word-Order Variation in Isaiah 40-55: A Functional Perspective, SSN 35 (Assen: Van Gorcum, 1997); Jacobus A. Naudé, review of WordOrder Variation in Isaiah 40-55: A Functional Perspective, by Michael Rosenbaum, OTE 12/1 (1999): 216-18.

58 Nicolai Winther-Nielsen, A Functional Discourse Grammar of Joshua: A Computer-Assisted Rhetorical Structure Analysis (Stockholm: Almqvist \& Wiksell, 1995). 
distributional patterns as the foundation of their research. ${ }^{59}$ Advances in computer technology and the availability of Biblical Hebrew linguistic databases are playing a role in this regard. ${ }^{60}$ Cognitive linguistic approaches to Biblical Hebrew are taking meaning back to the heart of its inquiry. Through the study of Biblical Hebrew language insight into the underlying system of human experiences, beliefs and practices is provided. ${ }^{61}$

In the twenty-first century, the second edition of the grammar of JoüonMuraoka in 2006 (and the second reprint in 2009) demonstrated its continued importance as a traditional, comprehensive grammar for the field. At the same time, the publication of the Encyclopedia of Hebrew Language and Linguistics in 2013 illustrates the value that various modern linguistic models have for better understanding a wide range of constructions and notions in all varieties of Hebrew. ${ }^{62}$

Important debates and developments further reflect the vitality of Biblical Hebrew linguistics in the twenty-first century. One important debate involves the challenge posed to traditional models for identifying and describing the diachronic character and phases of biblical and post-biblical Hebrew. ${ }^{63} \mathrm{New}$ hypotheses and new models for identifying and understanding language variation and change have been proffered and no consensus has been reached thus far. ${ }^{64}$

59 Janet W. Dyk and Eep Talstra, "Paradigmatic and Syntagmatic Features in Identifying Subject and Predicate in Nominal Clauses," in The Verbless Clause in Biblical Hebrew: Linguistic Approaches, ed. Cynthia L. Miller, LSAWS 1 (Winona Lake, IN: Eisenbrauns, 1999), 133-86.

60 Janet W. Dyk, Participles in Context: A Computer-Assisted Study of Old Testament Hebrew (Amsterdam: Free University Press, 1994); Francis I. Anderson and A. Dean Forbes, Biblical Hebrew Grammar Visualized, LSAWS 6 (Winona Lake, IN: Eisenbrauns, 2012).

61 Reinier de Blois, "Cognitive Linguistic Approaches to Biblical Hebrew," in Encyclopedia of Hebrew Language and Linguistics, ed. Geoffrey Khan (Leiden: Brill), 1:471-73.

62 Geoffrey Khan, ed., Encyclopedia of Hebrew Language and Linguistics, 4 vols. (Leiden: Brill, 2013).

63 Ian Young, Robert Rezetko, and Martin Ehrensvärd, The Linguistic Dating of Biblical Texts (London: Equinox, 2008); Robert Rezetko and Ian Young, Historical Linguistics and Biblical Hebrew: Steps Towards an Integrated Approach (Atlanta: SBL, 2014).

64 See, e.g., Aaron D. Hornkohl, Ancient Hebrew Periodization and the Language of the Book of Jeremiah: The Case for a Sixth Century Date of Composition, SSLL (Leiden: Brill, 2014); and the essays in Cynthia L. Miller-Naudé and Ziony Zevit, eds., Diachrony in Biblical Hebrew (Winona Lake, IN: Eisenbrauns, 2012). 


\section{Trends in South Africa}

Three eras can be distinguished in the evolution of Biblical Hebrew Linguistics in South Africa in the past 60 years. In the first era, the study of Biblical Hebrew in South Africa was primarily philological in nature and both teaching grammars and research focused on grammar, specifically phonetics, word formation, vocabulary and meaning. In the second era, the study of Biblical Hebrew in South Africa was heavily influenced by the new developments in Europe and the USA concerning linguistics and especially in the fields of Biblical Hebrew syntax and discourse analysis. In the third era, Biblical Hebrew linguistics in South Africa contributes to the development of the field by taking into account the complexity of Biblical Hebrew as a language.

\section{2a First Era (1953-1975)}

The first era in South Africa was dominated by the grammar written by B. Gemser who was professor in OT Sciences, first at the University of Pretoria and then at the Rijksuniversiteit in Groningen. ${ }^{65}$ On 1 June 1926 he was appointed as professor to found the department of OT at the University of Pretoria. He was also responsible for the teaching of Hebrew for undergraduate students who were following a BA degree. ${ }^{66}$ Later he founded the Department of Semitic Languages at Pretoria as well.

Gemser started to work on the grammar in 1950 and the first edition was published in 1953. ${ }^{67}$ The grammar reflects 33 years of experience of Hebrew language teaching. ${ }^{68}$ For the compilation of the grammar Prof Gemser received assistance from Prof A. van Selms and Dr A. H. van Zyl of Semitic languages at the University of Pretoria and Prof P. F. D. Weiss of Semitic Languages at the University of Stellenbosch as well as Drs E. S. Mulder and C. J. Labuschagne, who was a theological student at the time. ${ }^{69}$ In addition to the grammars of Gesenius-Kautzsch-Cowley and Bauer and Leander he also utilised inter alia the 1946 edition of the grammar of Davidson and the 1924 edition of the syntax of Davidson, the grammar of Ungnad, as well as the third edition of the Hebrew grammar of J. Nat as revised by J. J. Koopman. ${ }^{70}$

65 Berend Gemser, Hebreeuse Spraakkuns: Vormleer, Sinsleer en Oefeninge (Pretoria: J.L. Van Schaik, 1953 [1st ed.], 1960 [2nd ed.], 1968 [3rd ed.], 1975 [3rd ed., 2nd print]).

66 E. S. Mulder, "Die Wetenskaplike Betekenis van die Werk van Professor B. Gemser," HvTSt 7/2-3 (1951): 88.

67 Gemser, Hebreeuse Spraakkuns (1953), xi; see Mulder, "Wetenskaplike Betekenis," 95.

68 Gemser, Hebreeuse Spraakkuns (1953), ix.

69 Gemser, Hebreeuse Spraakkuns (1968), x-xi

70 Andrew B. Davidson, An Introductory Hebrew Grammar, 24th ed. (Edinburgh: T

\& T Clark, 1946); Andrew B. Davidson, Introductory Hebrew Grammar: Hebrew 
The grammar is divided into Curriculum $\mathrm{A}$ and $\mathrm{B}$, which cover respectively the first and second year of teaching. Curriculum A consists of two sections namely the writing system and morphology. Curriculum B covers a continuation of morphology which is followed by a section on syntax. The claim is that syntax received more attention in Gemser's grammar than in other grammars for beginners, which is true. The grammar covers the syntax of the noun (two chapters), verb (four chapters), the sentence (four chapters). ${ }^{71}$ Although the treatment of the sentence in a teaching grammar was very innovative, the treatment is very cryptic and lacks descriptive adequacy in many cases. ${ }^{72}$ A chapter on the rhythmic features of Hebrew and the Masoretic accents was added. ${ }^{73}$ Although basic syntax is represented it did not receive much attention in the second year of teaching. At the University of the Free State basic syntax formed part of the teaching of the third year curriculum until $1975 .^{74}$

The second edition was published in 1960, with the claim in the preface that new information had been added from the works of Brockelmann and Weingreen as well as from older grammars for example, Joüon, Grether, Meyer, Hollenberg-Budde. ${ }^{75}$ Seven years later (1967) the third edition was finished and published in $1968 .{ }^{76}$ Prof Gemser died in 1962 and the revision was done by Dr

Syntax, $3^{\text {rd }}$ ed. (Edinburgh: T \& T Clark, 1924); Arthur Ungnad, Hebräische Grammatik, HHU 1 (Tübingen: J.C.B. Mohr [Paul Siebeck], 1912); Jan Nat, Oefeningen bij de hebreeuwsche grammatica: stukken uit het Oude Testament en woordenlijsten, rev. J. J. Koopmans, 3rd ed. (Leiden: Brill, 1948); see Gemser, Hebreeuse Spraakkuns (1968), x.

71 Gemser, Hebreeuse Spraakkuns (1968), 192-264.

72 See the discussion concerning Gemser on the verbless clause in Section D below. The same pertains to the discussion of status constructus in paragraph 235 of Gemser, Hebreeuse Spraakkuns (1968), 198.

73 Gemser, Hebreeuse Spraakkuns (1968), 264-80.

74 Personal communication: Prof S. J. Riekert, who offered the module during this period.

75 Brockelmann, Hebräische Syntax; Jacob Weingreen, Practical Grammar for Classical Hebrew, 2nd ed. (Oxford: Oxford University Press, 1959); Joüon, Grammaire (1947); Oskar Grether, Hebräische Grammatik für den akademischen Unterricht (München: Evangelischer Presseverband für Bayern, 1951); Georg Beer, Hebräische Grammatik, GS, 2nd ed. by Rudolf Meyer (Berlin: Walter de Gruyter, 1952); Johannes Hollenberg and Karl Budde, Hebräisches Schulbuch, 18th ed., rev. Walter Baumgartner (Basel: Verlag Helbing \& Lichtenhahn, 1948); see Gemser, Hebreeuse Spraakkuns (1968), xii.

76 A comparison of the three editions shows that the revisions are minor which include addition of vocabulary, footnotes, reformulations and corrections. However, errors are still detected in the third edition. A second print of the third edition was published in 1975. 
C. J. Labuschagne, senior lecturer in Semitic Languages at the University of Pretoria. $^{77}$

Gemser's grammar was widely used as a teaching grammar until the beginning of the 1970s. Because its presentation was not actually that of a teaching grammar, scholars at a number of institutions wrote teaching grammars for their students, which they distributed in the form of photocopied notes. Such teaching grammars were compiled at the University of the Free State, Northwest University, University of Pretoria, University of South Africa and University of Stellenbosch and this practice is still on-going.

\section{2b Second Era (1976-2006)}

The second era in South Africa can be divided into two sub-parts. From 19761998, semantics dominated the application of linguistics to Biblical Hebrew. From 1999-2009, syntax and discourse dominated the application of linguistics to Biblical Hebrew.

\section{Dominant Semantic Phase (1976-1998)}

Beginning in 1973 the Bible translator Eugene Nida visited South Africa frequently. ${ }^{78} \mathrm{He}$ contributed to semantic analysis through developing componential analysis to determine the meanings of words. ${ }^{79}$ This influenced the research of Prof Johannes Louw on the semantics of NT Greek, resulting in his 1976 publication in which he discussed semantics as a new field of study (chs. 1-3), the etymological fallacy (ch. 4), the nature of meaning (chs. 5-10), the relation between semantics and language structure - semantics is more than the meaning of sentences (chs. 11-12). ${ }^{80}$ This work influenced not only lexical meaning but also structural analysis/discourse analysis and was also studied by Biblical Hebrew students and scholars in conjunction with the works of James Barr and Eugene Nida. ${ }^{81}$ Attention to the semantic fields of Biblical Hebrew

77 Gemser, Hebreeuse Spraakkuns (1968), xii.

78 For example, his 1981 lectures are published as Eugene A. Nida, Signs, Sense, Translation (Pretoria: University of Pretoria, 1981).

79 F. Charles Fensham, "Die Verlede, Hede en Toekoms van Grammatikale Arbeid op Bybelse Hebreeus," Taalf 17 (1973): 9-10.

80 Johannes P. Louw, Semantiek van Nuwe Testamentiese Grieks (Pretoria: Universiteit van Pretoria, Departement Grieks, 1976).

81 James Barr, The Semantics of Biblical Language (London: Oxford University Press, 1961); James Barr, Comparative Philology and the Text of the Old Testament (London: Oxford University Press, 1968); Eugene A. Nida and Charles R. Taber, The Theory and Practice of Translation, HTrans 8 (Leiden: E.J. Brill, 1969). See Ferdinand E. Deist, "ktmr mqsh in Jer 10,5," ZAW 85 (1973): 225-26; Ferdinand E. Deist, "'appayim pym? (1Sam 1,5)," VT 27 (1977): 205-9. 
continued to play a role in South African scholarship. ${ }^{82}$ In 1997, the New International Dictionary of Old Testament Theology and Exegesis was published with ten South African scholars writing entries on various semantic fields within the OT. ${ }^{83}$ However, an unfortunate result of this development was neglect of formal syntax.

\section{Dominant Syntactic and Discourse Phase (1999-2006)}

In 1999, the Biblical Hebrew Reference Grammar (BHRG) was published by three South African scholars as an intermediate level grammar. ${ }^{84}$ The $B H R G$ ushered in a new phase in South Africa in which the study of Biblical Hebrew turned to focus on syntax and discourse. The $B H R G$ incorporates existing knowledge of Biblical Hebrew as found especially in the grammars of GeseniusKautzsch-Cowley, Richter, Waltke and O'Connor, and Joüon-Muraoka. ${ }^{85}$

Although the $B H R G$ did not attempt to be "linguistically innovative," research of the 1990s by the authors on Biblical Hebrew linguistics was incorporated, especially with respect to the discussions on construct relationships, pronouns, focus particles, some conjunctions and word order. ${ }^{86}$ Examples are as follows: For describing "emphasising constructions," Christo van der Merwe utilised some of the principles Richter would adhere to, for example, the identification of well-defined functional classes, as well as "focus," which is the referent of the item marked for focus because it represents a particular item from a number of possible alternatives, while the background item involves no alternatives. ${ }^{87}$ The generative studies of Naudé and Snyman contributed to the study of inter alia the following phenomena in Biblical Hebrew: the nature and distribution of subjects, pronouns and pronominal clitics, resumption, constituent order, scope of negation and the syntax and semantics of

82 For example, Jacobus A. Naudé, "Holiness in the Dead Sea Scrolls," in The Dead Sea Scrolls after Fifty Years: A Reappraisal, ed. Peter Flint and James C. VanderKam (Leiden: Brill, 1999), 171-99.

83 Willem vanGemeren, ed., New International Dictionary of Old Testament Theology and Exegesis (Grand Rapids: Zondervan, 1997). The ten scholars are Hendrik L. Bosman, Johann Cook, I. Cornelius, Paul A. Kruger, Jacobus A. Naudé, Philip J. Nel, D. F. O'Kennedy, Daniel N. Pienaar, Harry F. Van Rooy and P. A. Verhoef.

84 Van der Merwe, Naudé, and Kroeze, Biblical Hebrew (1999). An Afrikaans version was published earlier: Christo H. J. van der Merwe, Jacobus A. Naudé, and Jan H. Kroeze, 'n Bybels-Hebreeuse Naslaangrammatika (Kaapstad: Nasionale boekdrukkery-groep, 1997). A first draft of BHRG was finished in the first half of the decade.

85 GKC; Richter, Die Wortfügung; Richter, Der Satz; Waltke and O'Connor, Introduction; Joüon and Muraoka, Grammar (2009).

86 Van der Merwe, Naudé and Kroeze, (1999), Biblical Hebrew, 11.

87 Christo H. J. van der Merwe, The Old Hebrew Particle gam: A Syntactic-Semantic Description of gam in $\mathrm{Gn}$-2Kg, ATSAT 34 (Ottilien: EOS Verlag, 1990). 
verbless predicates. ${ }^{88}$ Jan Kroeze's description of the syntactic and semantic functions of construction phrases and other sentence-constituents is from a functional-sentence perspective. ${ }^{89}$ This approach was also used by Christo van der Merwe to describe the function of Biblical Hebrew word order. ${ }^{90}$ An important exception to the focus on syntax and discourse analysis was the book by Andries Coetzee on Tiberian Hebrew Phonology in 1999. ${ }^{91}$ Realising that $B H R G$ had become outdated in light of developments in general linguistics, on the one hand, and new research on Biblical Hebrew linguistics, on the other hand, the process of revising $B H R G$ for a second edition started officially in $2007 .{ }^{92}$

\section{Third Era (2007-Present)}

We distinguish a third era as beginning in 2007 and continuing to the present, even though it may be too early to be sure that this is really a third era and not a continuation of the previous era.

As we have delineated the history, the third era is distinguished by the participation of South Africans in international research on Biblical Hebrew as well as in the leadership of inter alia the Linguistics and Biblical Hebrew programme unit at the annual meeting of the Society of Biblical Literature in the

88 See for example: Jacobus A. Naudé, "On Subject Pronoun and Subject Noun Asymmetry: A Preliminary Survey of Northwest Semitic," SAJL 11/1 (1993): 17-28; Jacobus A. Naudé, "The Transitions of Biblical Hebrew in the Perspective of Language Change and Diffusion," in Biblical Hebrew: Chronology and Typology, ed. Ian Young, JSOTSup 369 (Sheffield: Sheffield Academic Press, 2003), 189-215; F. P. J. Snyman, The Scope of the Negative Lo' in Biblical Hebrew, AAcSup (Bloemfontein: UV-SasolBiblioteek, 2004).

89 Jan H. Kroeze, "Semantic Relations in Construct Phrases of Biblical Hebrew: A Functional Approach," ZAH 10/1 (1997): 27-41.

90 Christo H. J. van der Merwe, "The Function of Word Order in Old Hebrew - With Special Reference to Cases where a Syntagmeme Precedes a Verb in Joshua," JNSL 17 (1993): 129-44; see also Christo H. J. van der Merwe, "Explaining Fronting in Biblical Hebrew," JNSL 17 (1999): 173-86.

91 Andries W. Coetzee, Tiberian Hebrew Phonology: Focusing on Consonant Clusters, SSN 38 (Assen: Van Gorcum, 1999).

92 See as examples for developments in linguistics, Christo H. J. van der Merwe, "Some Recent Trends in Biblical Hebrew Linguistics: A Few Pointers towards a More Comprehensive Model of Language Use," HS 44 (2003): 7-24; Christo H. J. van der Merwe, "A Cognitive Linguistic Perspective on הנה in the Pentateuch, Joshua, Judges, and Ruth," HS 48 (2007): 101-40; Christo H. J. van der Merwe, "Another Look at the Biblical Hebrew Focus Particle םג, JSS 14/2 (2009): 313-32. 
USA and the National Association of the Professors of Hebrew. ${ }^{93}$ The papers of a joint session of these societies in 2015 on Editing the Hebrew Bible and Historical Linguistics were published in the South African Journal for Semitics in 2016. Since volume 6 (2012) the two editors of the book series Linguistic Studies in Ancient West Semitic, published by the USA publisher, Eisenbrauns, are South Africans.

The third era also relates to an international paradigm shift from a reductionist approach to language involving a single dimension or modality of reality (which characterised the modernist approach) to a complexity approach, which sees language as a set of simultaneous, interacting understandings with an open interplay of multiple interacting elements and forces. ${ }^{94}$ This new theoretical perspective has been shown to have significant implications for analysing the grammar of Biblical Hebrew. ${ }^{95}$

Another new development in Biblical Hebrew linguistics involves the use of typological cross-linguistic studies of language to understand how Biblical Hebrew fits into the limited number of patterns exhibited among the world's languages. Typological linguistics also has implications for teaching Biblical Hebrew, especially to non-Western students, without the metalinguistic categories of traditional grammars, which are based on European languages. ${ }^{96}$

In 2013, the Encyclopedia of Hebrew Language and Literature was published. ${ }^{97}$ It includes articles by six South African scholars; these scholars are also listed in the subject index as contributing to the field. ${ }^{98}$

93 Jacobus A. Naudé has served on the steering committee of Linguistics and Biblical Hebrew from 2010-2015 and as programme unit chair from 2015 to the present. Cynthia L. Miller-Naudé served as President of National Association of the Professors of Hebrew from 2014 until 2016 and Jacobus A. Naudé on the Advisory Council (PreModern Division) of this association since 2017.

94 Complexity theory has been applied to translation studies by a South African scholar; see Kobus Marais, Translation Theory and Development Studies: A Complexity Theory Approach, RATS 4 (New York: Routledge, 2014).

95 Jacobus A. Naudé, "Diachrony in Biblical Hebrew and a Theory of Language Change and Diffusion," in Diachrony in Biblical Hebrew, ed. Cynthia L. Miller-Naudé and Ziony Zevit (Winona Lake, IN: Eisenbrauns, 2012), 182; Christo H. J. van der Merwe and Alexander Andrason, "Finite Infinite? 'Finite' Uses of the Biblical Hebrew Infinitive Absolute and their Rationale," JSS 59/1 (2014): 255-96.

96 Jacobus A. Naudé and Cynthia L. Miller-Naudé, “A New Biblical Hebrew Teaching Grammar for African Bible Translators: A Typological Approach.” OTE 24/3 (2011): 690-707.

97 Khan, ed., Encyclopedia.

98 The articles are by Theo J. D. Bothma, Jan Kroeze, Machdel C. Matthee, Cynthia L. Miller-Naudé, Jacobus A. Naudé, and Christo H. J. van der Merwe. 
In 2017, the second edition of the Biblical Hebrew Reference Grammar was published. The second edition retains the foundations of the classical grammars of Gesenius-Kautzsch-Cowley, Richter, Waltke and O'Connor, Joüon-Muraoka (including the second edition of this grammar). However, this completely revised and substantially enlarged edition incorporates insights gleaned from the wealth of recent research in the field of Biblical Hebrew linguistics, especially with respect to pronouns, prepositions, quantifiers, discourse particles, negation, the verbal system and word order. While striving to remain theoretically neutral in its presentation, many recent developments from general linguistics, especially formal grammar, historical linguistics, linguistic typology, cognitive linguistics, semantics, pragmatics and sociolinguistics, are taken into account. In addition, the advances introduced by the on-going publication of Biblia Hebraica Quinta are indicated.

A book entitled Linguistics for Hebraists and Biblical Scholars is currently in preparation. Edited by Cook and Holmstedt, the book will contain chapters which introduce various linguistic theories and sub-disciplines for biblical scholars using examples from Biblical Hebrew. ${ }^{99}$ Three South African scholars were invited to write chapters for the volume.

\section{IMPACT OF LINGUISTICS ON BIBLICAL HEBREW-THE VERBLESS CLAUSE AS A CASE IN POINT}

We turn now to a specific example of the impact of linguistics on Biblical Hebrew grammatical description, namely, the verbless clause with pleonastic pronoun in Biblical Hebrew. This construction is also known as the "tripartite verbless clause." It consists of two nominal phrases and a pronominal element, which may be either the second or third constituent. Example (1) illustrates the pronoun as the second constituent:

(1) Genesis 9:18

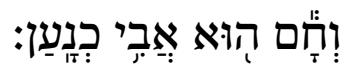

And Ham PRONOUN father of Canaan

Example (2) illustrates the pronoun as the third constituent:

(2) 2 Kings 7:9

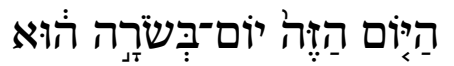

This day a day of good news PRONOUN

99 John A. Cook and Robert D. Holmstedt, eds., Linguistics for Hebraists and Biblical Scholars, LSAWS (Winona Lake, IN: Eisenbrauns, forthcoming). 
The earliest European grammars from the 19th century understood the pronominal element in one of two ways. The first approach was to view the pronominal element as a copular constituent, which bound together the two nominal elements in a sentence in place of the copular verb hây $\hat{a}$. Albrecht 1887 and 1888 as well as Brockelmann 1956 took this approach. ${ }^{100}$ They would translate (1) as "Ham is the father of Canaan" and (2) as "this day is a day of good news." The pronoun thus does not contribute to the meaning of the sentences.

The second approach has been to view the pronominal element as the resumptive element of a left dislocated constituent. Gesenius-Kautzsch-Cowley 1910 was an early proponent of this approach. ${ }^{101}$ Left dislocation involves a constituent which appears at the front (left) edge of a sentence outside of the sentence proper; the left dislocated constituent is resumed within the sentence by a pronominal element with which it agrees and is co-referential. Example (1) would then be translated "as for the Ham, he is the father of Canaan" and example (2) would be translated "as for this day, it is a day of good news." The pronominal element is thus the subject of the sentence and the first constituent provides the topic or focus of the sentence.

In the first era of Biblical Hebrew in South Africa, the grammar of Gemser was highly influential. Gemser referred to sentences without a finite verb as "nominal sentences". ${ }^{102}$ With respect to the tripartite verbless clauses, he combined the two main syntactic interpretations to say that the independent pronoun of the third person is used as a copula as a kind of resumption of the subject, a kind of casus pendens. ${ }^{103}$ However, all the examples he discusses are interpreted/translated with the function of a copula and not as dislocations.

In the second era, the study of Biblical Hebrew in South Africa was heavily influenced by the new developments in Europe and the USA concerning linguistics and especially in the fields of Biblical Hebrew syntax and discourse analysis. With respect to the verbless clause, in general, and the tripartite clause, in particular, great advances in linguistic understanding were made. In 1970, Francis Andersen, an Australian studying and later teaching in the USA for a time, produced an entire volume on the linguistic analysis of every verbless clause in the Pentateuch. ${ }^{104}$ His contribution was to see the word order of the subject and predicate of the verbless clause as having semantic and pragmatic

100 C. Albrecht, "Die Wortstellung im hebräischen Nominalsatze," ZAW 7 (1887): 21824; C. Albrecht, "Die Wortstellung im hebräischen Nominalsatze: Teil II." ZAW 8 (1888): 249-63; Brockelman, Hebräische Syntax.

101 GKC, $\$ 141 \mathrm{~g}-\mathrm{h}$.

102 Gemser, Hebreeuse Spraakkuns, 235-36.

103 Gemser, Hebreeuse Spraakkuns, 236.

104 Francis I. Andersen, The Hebrew Verbless Clause in the Pentateuch, JBLMS 14 (Nashville: Abingdon, 1970). 
value, by distinguishing verbless clauses whose function is to identify the subject as opposed to those whose function is to classify the subject. Andersen's approach to verbless clauses was popularised by its inclusion in the grammar of Waltke and O'Connor in 1990. ${ }^{105}$

With respect to the analysis of tripartite verbless clauses, the second approach which views the pronominal element as the subject within a left dislocation construction gained ground. The Israeli scholar Tamar Zewi published extensively on this analysis within the context of the other Northwest Semitic languages. ${ }^{106}$ The important grammar by Joüon-Muraoka also took this approach and popularised it. ${ }^{107}$ Linguistic analysis of the verbless clause was also enhanced by the volume edited by Miller on the verbless clause in $1999 .{ }^{108}$ Many of the articles in that volume originated in the Linguistics and Biblical Hebrew section of the Society of Biblical Literature annual meeting in 1996 and represent the cutting-edge application of linguistics to the question by American and European scholars; no South African scholars contributed articles although their work is sometimes cited. ${ }^{109}$

In South Africa, there were two main scholars working on the verbless clause and the tripartite verbless clause. Christo van der Merwe, working with Tamar Zewi, examined the various linguistic arguments for identifying the subject and the predicate of the verbless clause. ${ }^{110}$ However, their work was not picked up and adopted in American and European circles. ${ }^{111}$ Jacobus Naudé published a number of articles on the verbless clause in Biblical Hebrew, Qumran Hebrew and Biblical Aramaic. ${ }^{112}$ His major contribution to the linguistic

105 Waltke and O’Connor, Introduction, $\$ 8.4$.

106 Tamar Zewi, "Subordinate Sentences Involving Prolepsis in Biblical Hebrew," JSS 41 (1996): 1-20; Tamar Zewi, "The Definition of the Copula and the Role of 3rd Independent Personal Pronouns in Nominal Sentences of Semitic Languages," FLH 17/1-2 (1996): 41-55; Tamar Zewi, "Tripartite Nominal Clauses and Appositional Clauses in Biblical Hebrew," ANES 36 (1999): 36-47; Tamar Zewi, "Is There a Tripartite Nominal Sentence in Biblical Hebrew?” JNSL 26/2 (2000): 51-63.

107 Joüon and Muraoka, Grammar (2009), §154i-j.

108 Cynthia L. Miller, ed., The Verbless Clause in Biblical Hebrew: Linguistic Approaches, LSAWS 1 (Winona Lake, IN: Eisenbrauns, 1999).

109 Naudé's work is cited on pp. 115, 187; van der Merwe's work is cited on pp. 39, 218.

110 Tamar Zewi and Christo H. J. van der Merwe, "Biblical Hebrew Nominal Clause: Definitions of Subject and Predicate," JNSL 27/1 (2001): 81-99.

111 For example, Joüon and Muraoka, Grammar (2009), cite other works by Tamar Zewi and by Christo van der Merwe, but not their joint article on the nominal clause.

112 Jacobus A. Naudé, "A Syntactic Analysis of Dislocation in Biblical Hebrew," JNSL 16 (1990): 115-30; Jacobus A. Naudé, "Aspects of the Verbless Clause in Biblical Aramaic," SAJL 11 (1993): 49-63; Jacobus A. Naudé, "The Verbless Clause with Pleonastic Pronoun in Biblical Aramaic," JSem 6 (1994): 74-93; Jacobus A. Naudé, 
analysis of the tripartite verbless clause was his use of the Masoretic accents to identify a tripartite verbless construction that involves a left dislocated constituent when there is a disjunctive accent on the first constituent as illustrated in (1), repeated here:

(1) Genesis 9:18

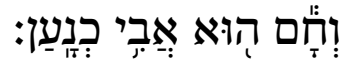

And Ham [disjunctive accent], he was the father of Canaan.

By contrast, when the first constituent is joined to the pronominal element

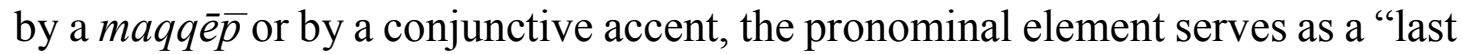
resort" strategy for ensuring that the first constituent is interpreted as the subject of the sentence. An example is given in (3):

Nehemiah 9:7

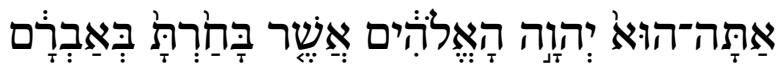

You $[$ maqqēp] are the LORD, the God who chose Abram...

The first constituent is the second person pronoun 'attâ "you." The third person pronominal element $h \bar{u}$ ' is joined to 'attâ with a maqqēp. It serves to ensure that the sentence is syntactically interpreted as "You are the LORD, the God who chose Abram..." and not as "you, O LORD, are the God who chose Abram..."

During the second era, Naudé's analysis of the tripartite verbless clause was ignored. It is curious that Muraoka cites Naudé's work at the beginning of his article in 1999 on the tripartite verbless clause as new research that should be added to the first edition of the grammar; ${ }^{113}$ Naudé's article was not cited or discussed in the second edition of the grammar published in 2006, even though his article on the ethical dative was cited in Joüon-Muraoka's grammar. ${ }^{114}$

In the third (contemporary) era, extensive new research from a linguistic point of view is taking place on the verbless clause and the tripartite verbless clause. The Australian scholar David Kummerow argues in 2013 for the copular analysis of the tripartite verbless clause using a diachronic argument that the

\footnotetext{
"Syntactic Aspects of Co-ordinate Subjects with Independent Personal Pronouns," JNSL 25/2 (1999): 75-99; Jacobus A. Naudé, "The Third Person Pronoun in Tripartite Verbless Clauses of Qumran Hebrew," in Pronouns: Representation and Grammar, ed. H. J. Simon and H. Wiese (Amsterdam: Benjamins, 2002), 161-82.

113 See Takamitsu Muraoka, "The Tripartite Nominal Clause Revisited," in The Verbless Clause in Biblical Hebrew: Linguistic Approaches, ed. Cynthia L. Miller, LSAWS 1 (Winona Lake, IN: Eisenbrauns, 1999), 187 n. 3.

114 Joüon and Muraoka, Grammar (2009), §133d.
} 
copular function developed out of the left dislocation construction. ${ }^{115}$ Although he cites and discusses Naudé's work on the construction and even uses some of Naudé's observations, he does not understand Naudé's proposal and rejects it. ${ }^{116}$

In 2014, an important article by Holmstedt and Jones is published on the tripartite verbless clause. ${ }^{117}$ They adopt a mediating position based upon the semantic-pragmatic function of the first constituent. In cases where the first constituent is pragmatically a topic and the pronoun agrees with it in person, gender and number, they see the construction as left dislocation, as in (4):

(4) 1 Samuel 17:14

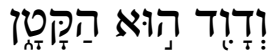

And as for David, he was the young(est).

In cases where the first constituent is not the topic of a topic-focus construction, they analyse the pronominal element as copular, as in (5):

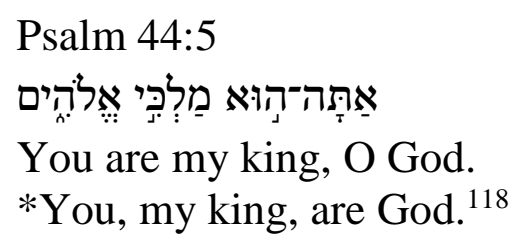

According to Holmstedt and Jones, the left dislocation analysis is precluded in (5) by the fact that there is no person agreement between the first constituent and the pronominal element; as a result, the pronoun cannot be a resumptive pronoun, thus precluding the left dislocation analysis. They also do not see the sentence as pragmatically expressing a topic-focus structure. Although they do take notice of Naudé's last resort strategy, they do not interact with it at length and they do not mention the prosodic component of it, even though they utilise his argument that the pronominal element joined with a maqqe $\bar{p}$ must be a clitic and not the subject pronoun. ${ }^{119}$ But at least the distinctively South African contribution to the linguistic analysis of Biblical Hebrew is discussed in the most important American and European venues in the third era.

115 David Kummerow, "Object Predication in Tiberian Hebrew - A Typological Approach to the Nonverbal Copula," KUSATU 16 (2013): 1-135.

116 Kummerow, "Object Predication," 43-46.

117 Robert D. Holmstedt and Andrew R. Jones, "The Pronoun in Tripartite Verbless Clauses in Biblical Hebrew: Resumption for Left-Dislocation or Pronominal Copula?" JSS 59/1 (2014): 53-89.

118 In accordance with linguistic practice, the asterisk indicates that the sentence is not possible.

119 Holmstedt and Jones, "Pronoun in Tripartite" 3, 4, 13, 15, 24; on the utilisation of Naudé's argument concerning maqqēe $\bar{p}$ and the pronoun as a clitic, see p. 62. 
Before concluding, we mention briefly the exegetical importance of differentiating left dislocation constructions and tripartite verbless clauses with a pronominal element as a "last resort" strategy for identification of the subject of a verbless clause.

One of the most interesting verses in this regard is Lam 1:18: ${ }^{120}$

Lamentations 1:18

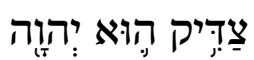

A righteous one is the LORD.

The conjunctive accent on the first constituent and the pronoun which follows it indicates that the sentence should be interpreted as "A righteous one is the LORD" and not "The LORD is righteous." The pronominal element $h \bar{u}$ " prevents the reader from the incorrect interpretation that the LORD is the subject of the sentence. Within the context of the passage, a contrast is made between who is the righteous one (namely, the LORD) as opposed to the rebellion of the speaker. The 1953 Afrikaans translation comes close to this interpretation by translating "Regverdig is Hy, die HERE." By contrast, the 1983 Afrikaans translation and most English translations make the LORD the subject of the sentence: "Die Here het reg gedoen" (Afrikaans 1983); "The LORD is in the right" (NRSV); "The LORD is righteous" (NIV). A linguistic understanding of the construction thus make a critical contribution to the exegesis of the passage.

\section{E CONCLUSIONS}

In conclusion, we have outlined the emergence and development of linguistics in the last sixty years and its appropriation for the description of Biblical Hebrew. We have shown that South Africa has played a progressively greater role in this endeavour, especially in the last decade. We have also shown that linguistics has proven to be important for the study of Biblical Hebrew theological dictionaries, such as the New International Dictionary of Old Testament Theology and Exegesis. Finally, we have shown how a linguistic analysis of tripartite verbless clauses has direct implications for OT exegesis.

\section{BIBLIOGRAPHY}

Albrecht, C. "Die Wortstellung im hebräischen Nominalsatze.” ZAW 7 (1887): 218-24. https://doi.org/10.1515/zatw.1887.7.1.218b

. "Die Wortstellung im hebräischen Nominalsatze: Teil II." ZAW 8 (1888): 249-63. https://doi.org/10.1515/zatw.1888.8.1.249

120 This example was also discussed in Jacobus A. Naudé and Cynthia L. MillerNaudé, "At the Interface of Syntax and Prosody: Differentiating Left Dislocated and Tripartite Verbless Clauses in Biblical Hebrew," SPL 48 (2017): 223-38. 
Andersen, Francis I. The Hebrew Verbless Clause in the Pentateuch. JBLMS 14. Nashville: Abingdon, 1970. . The Sentence in Biblical Hebrew. New York: Mouton, 1974.

Anderson, Francis I. and A. Dean Forbes. Biblical Hebrew Grammar Visualized. LSAWS 6. Winona Lake, IN: Eisenbrauns, 2012. https://doi.org/10.1515/9783111356808

Barr, James. The Semantics of Biblical Language. Oxford: Oxford University Press, 1961.

Comparative Philology and the Text of the Old Testament. Oxford: Oxford University Press, 1963.

Bauer, Hans and Pontus Leander. Historische Grammatik der Hebräischen Sprache des Alten Testaments. Halle: Verlag von Max Niemeyer, 1922.

Beer, Georg. Hebräische Grammatik. 2nd ed by R. Meyer. Berlin: Walter de Gruyter, 1952.

Bergen, Robert B., ed. Biblical Hebrew and Discourse Linguistics. Winona Lake, IN: Eisenbrauns, 1994.

Bergsträsser, Gotthelf. Hebräische Grammatik: Mit Benutzung der von E. Kautzsch bearbeiten 28. Auflage von Wilhelm Gesenius' hebräischer Grammatik. Hildesheim: Georg Olms Verlag, repr. 1962.

Bloomfield, Leonard. Language. New York: Holt, Rinehart and Winston, 1933.

Bodine, Walter R., ed. Linguistics and Biblical Hebrew. Winona Lake, IN: Eisenbrauns, 1992.

Borer, Hagit. "Generative Grammar and Hebrew." Pages 23-42 in vol. 2 of Encyclopedia of Hebrew Language and Linguistics. Edited by Geoffrey Khan. Leiden: Brill, 2013.

Botha, Rudolf P. The Conduct of Linguistic Inquiry. The Hague: Mouton Publishers, 1981. https://doi.org/10.1515/9783110822946

Brockelmann, Carl. Hebräische Syntax. Neukirchen-Vluyn: Neukirchener Verlag, 1956.

. Grundriss der vergleichenden Grammatik der semitischen Sprachen. 2 vols. Hildesheim: Georg Olms Verlag, repr. 1966.

Brody, Robert. Sa'adyah Gaon. Oxford: The Littman Library of Jewish Civilization, 2013.

Buth, Randall J. "Functional Grammar, Hebrew and Aramaic: An Integrated, Textlinguistic Approach to Syntax." Pages 77-102 in Discourse Analysis of Biblical Literature: What It Is and What It Offers. Edited by Walter R. Bodine. Winona Lake, IN: Eisenbrauns, 1995.

Chomsky, Noam. Syntactic Structures. The Hague: Mouton, 1957.

Chomsky, William. David Kimhi's Hebrew Grammar (Mikhlol). New York: Bloch Publishing Company, 1952.

Hebrew: The Eternal Language. Philadelphia: The Jewish Publication Society of America, 1957.

Coetzee, Andries W. Tiberian Hebrew Phonology: Focusing on Consonant Clusters. SSN 38. Assen: Van Gorcum, 1999.

Cohen, Mordechai. "The Qimhi Family." Pages 388-415 in The Middle Ages. Part 2 of From the Beginnings to the Middle Ages. Vol. 1 of Hebrew Bible/Old Testament: 
The History of Its Interpretation. Edited by Magne Sæbø. Göttingen: Vandenhoeck \& Ruprecht, 2000.

Cook, John A. and Robert D. Holmstedt, eds. Linguistics for Hebraists and Biblical Scholars. LSAWS. Winona Lake, IN: Eisenbrauns, forthcoming.

Davidson, Andrew B. Introductory Hebrew Grammar: Hebrew Syntax. 3rd edition. Edinburgh: T \& T Clark, 1924. . An Introductory Hebrew Grammar. 24th ed. Edinburgh: T \& T Clark, 1946.

Dawson, David A. Text-Linguistics and Biblical Hebrew. Sheffield: Sheffield Academic Press, 1994.

de Blois, Reinier. "Cognitive Linguistic Approaches to Biblical Hebrew." Pages 471 473 in vol. 1 of Encyclopedia of Hebrew Language and Linguistics. Edited by Geoffrey Khan. Leiden: Brill, 2013.

de Saussure, Ferdinand. Course in General Linguistics. New York: Philosophical Library, 1959.

DeCaen, Vincent. "Verbal and Verbless Clauses within Government-Binding Theory." Pages 109-131 in The Verbless Clause in Biblical Hebrew: Linguistic Approaches. Edited by Cynthia L. Miller. LSAWS 1. Winona Lake, IN: Eisenbrauns, 1999.

Deist, Ferdinand E. "ktmr mqsh in Jer 10,5." ZAW 85 (1973): 225-26. . "'appayim pym? (1Sam 1,5)." VT 27 (1977): 205-9.

Dik, Simon C. Functional Grammar. London: Academic Press, 1978. . The Theory of Functional Grammar. Dordrecht: Foris, 1989.

Dyk, Janet W. Participles in Context: A Computer-Assisted Study of Old Testament Hebrew. Amsterdam: Free University Press, 1994.

Dyk, Janet W. and Eep Talstra. "Paradigmatic and Syntagmatic Features in Identifying Subject and Predicate in Nominal Clauses." Pages 133-86 in The Verbless Clause in Biblical Hebrew: Linguistic Approaches. Edited by Cynthia L. Miller. LSAWS 1. Winona Lake, IN: Eisenbrauns, 1999.

Ellis, Nick C. and Diane Larsen-Freeman, eds. Language as a Complex Adaptive System. Chichester: John Wiley and Sons, 2009.

Fassberg, Steven E. "The Linguistic Context of Biblical Hebrew and Aramaic in the Framework of Semitic Philology, Including Semitic Epigraphy.” Pages 45-57 in The Twentieth Century - From Modernism to Post-Modernism. Part 2 of From Modernism to Post-Modernism (The Nineteenth and Twentieth Centuries). Volume 3 of Hebrew Bible/Old Testament: The History of Its Interpretation. Edited by Magne Sæbø. Göttingen: Vandenhoeck \& Ruprecht, 2015.

Fensham, F. Charles. "Die Verlede, Hede en Toekoms van Grammatikale Arbeid op Bybelse Hebreeus." Taalfasette 17 (1973): 1-11. https://doi.org/10.1080/04966 740.1973.10587955

Finch, Geoffrey. Key Concepts in Language and Linguistics. 2nd ed. New York: Palgrave MacMillan, 2005.

Gemser, Berend. Hebreeuse Spraakkuns: Vormleer, Sinsleer en Oefeninge. Pretoria: J.L. Van Schaik, 1953 [1st ed.], 1960 [2nd ed.], 1968 [3rd ed.], 1975 [3rd ed., 2nd print].

Gesenius, Wilhelm, Emile Kautzsch, and E. Arthur Cowley. Gesenius' Hebrew Grammar. 2nd ed. Oxford: Blackwell, 1910. 
Givón, Talmy. The Genesis of Syntactic Complexity: Diachrony, Ontogeny, Neurocognition, Evolution. Philadelphia: John Benjamins, 2009. https://doi.org/10.1 $\underline{075 / \mathrm{z} .146}$

Grether, Oskar. Hebräische Grammatik für den akademischen Unterricht. München: Evangelischer Presseverband für Bayern, 1951.

Gross, Walter. Die Pendenskonstruktion im biblischen Hebräisch. ATSAT 27. St. Ottilien: EOS Verlag, 1987.

Gzella, Holger. "Expansion of the Linguistic Context of the Hebrew Bible/Old Testament: Hebrew among the Languages of the Ancient Near East." Pages 13467 in The Nineteenth Century - a Century of Modernism and Historicism. Part 1 of From Modernism to Post-Modernism (The Nineteenth and Twentieth Centuries). Vol. 3 of Hebrew Bible/Old Testament: The History of Its Interpretation. Edited by Magne Sæbø. Göttingen: Vandenhoeck \& Ruprecht, 2000.

Halliday, Michael A.K. An Introduction to Functional Grammar. London: Arnold, 1994.

Halliday, Michael A.K. and Christian M. I. M. Matthiessen. An Introduction to Functional Grammar. 3rd ed. London: Arnold, 2004.

Harris, Zellig S. Structural Linguistics. Chicago: Chicago University Press, 1961.

Heimerdinger, Jean-Marc. Topic, Focus and Foreground in Ancient Hebrew Narrative. JSOTSup 295. Sheffield: Sheffield Academic Press, 1999.

Hjelmslev, Louis. Principes de Grammaire Générale. Copenhagen: Høst \& Søn, 1928. Hollenberg, Johannes and Karl Budde. Hebräisches Schulbuch. 18th ed. Revised by Walter Baumgartner. Basel: Verlag Helbing \& Lichtenhahn, 1948.

Holmstedt, Robert D. The Relative Clause in Biblical Hebrew. LSAWS 10. Winona Lake, IN: Eisenbrauns, 2016.

Holmstedt, Robert D. and Andrew R. Jones. "The Pronoun in Tripartite Verbless Clauses in Biblical Hebrew: Resumption for Left-Dislocation or Pronominal Copula?" JSS 59/1 (2014): 53-89. https://doi.org/10.1093/jss/fgt035

Hornkohl, Aaron D. Ancient Hebrew Periodization and the Language of the Book of Jeremiah: The Case for a Sixth Century Date of Composition. SSLL. Leiden: Brill, 2014. https://doi.org/10.1163/9789004269651

Jakobson, Roman. Language in Literature. Cambridge, MA: The Belknapp Press of Harvard University Press, 1987.

Joüon, Paul. Grammaire de l'Hébreu biblique. Rome: Institut Biblique Pontifical, 1923 [1st ed.], 1947 [2nd ed.].

Joüon, Paul and Takamitsu Muraoka. A Grammar of Biblical Hebrew. Rome: Pontifical Biblical Institute, 1991 [1st ed.], 2006 [2nd ed.], 2009 [2nd ed. with corrections].

Kessler-Mesguish, Sophie. "Early Christian Hebraist." Pages 254-72 in From the Renaissance to the Enlightenment. Vol. 2 of Hebrew Bible/Old Testament: The History of Its Interpretation. Edited by Magne Sæbø. Göttingen: Vandenhoeck \& Ruprecht, 2008.

Khan, Geoffrey ed. Encyclopedia of Hebrew Language and Linguistics. Four volumes. Leiden: Brill, 2013.

König, Friedrich E. Historisch-kritisches Lehrgebäude der hebräischen Sprache. 3 vols. Hildesheim: Georg Olm Verlag, 1881-1897; repr. 1979. 
Kroeze, Jan H. "Semantic Relations in Construct Phrases of Biblical Hebrew: A Functional Approach." ZAH 10/1 (1997): 27-41.

Kropat, Arno. Die Syntax des Autors der Chronik verglichen mit der seiner Quellen: Ein Beitrag zur historischen Syntax des Hebräischen. BZAW 16. Giessen: Alfred Töpelmann, 1909.

Kummerow, David. "Object Predication in Tiberian Hebrew - A Typological Approach to the Nonverbal Copula." KUSATU 16 (2013): 1-135.

Lakoff, George and Mark Johnson. Metaphors We Live By. Chicago: University of Chicago Press, 1980.

Lakoff, George and Mark Turner. More than Cool Reason. Chicago: University of Chicago Press, 1989. https://doi.org/10.7208/chicago/9780226470986.001.0001

Lamb, Syndney M. Outline of Stratificational Grammar. Washington, D.C.: Georgetown University Press, 1966.

Larson-Freeman, Diane and Lynne Cameron. Complex Systems and Applied Linguistics. Oxford: Oxford University Press, 2008.

Longacre, Robert E. Joseph: A Story of Divine Providence: A Text Theoretical and Textlinguistic Analysis of Genesis 37 and 39-48. Winona Lake, IN: Eisenbrauns, 1989.

Louw, Johannes P. Semantiek van Nuwe Testamentiese Grieks. Pretoria: Universiteit van Pretoria, Departement Grieks, 1976.

Lyons, John. Introduction to Theoretical Linguistics. Cambridge: Cambridge University Press, 1968. https://doi.org/10.1017/CBO9781139165570

Malone, Joseph L. Tiberian Hebrew Phonology. Winona Lake, IN: Eisenbrauns, 1993.

Marais, Kobus. Translation Theory and Development Studies: A Complexity Theory Approach. RATS 4. New York: Routledge, 2014.

Meyer, Rudolf. Hebräische Grammatik. SG. 3rd ed. Berlin: De Gruyter, 1966-1972.

Miller, Cynthia L. The Representation of Speech in Biblical Hebrew Narrative: A Linguistic Analysis. HSM 55. Atlanta: Scholars Press, 1996.

. Review of A Study in Divine Providence: A Text Theoretical and TextLinguistic Analysis of Genesis 37 and 39-48, by Joseph Longacre. JNES 56 (1997): 155-56.

. ed. The Verbless Clause in Biblical Hebrew: Linguistic Approaches. LSAWS 1. Winona Lake, IN: Eisenbrauns, 1999.

"Methodological Issues in Reconstructing a Language System from Epigraphic Fragments." Pages 281-305 in The Future of Biblical Archaeology: Reassessing Methods and Assumptions. Edited by James K. Hoffmeier and Alan Millard. Grand Rapids: Eerdmans, 2004.

Miller-Naudé, Cynthia L. and Ziony Zevit, eds. Diachrony in Biblical Hebrew. Winona Lake, IN: Eisenbrauns, 2012.

Mulder, E.S. "Die Wetenskaplike Betekenis van die Werk van Professor B. Gemser." HvTSt 7/2-3 (1951): 85-96. https://doi.org/10.4102/hts.v7i2/3.3628

Muraoka, Takamitsu. "The Tripartite Nominal Clause Revisited." Pages 187-213 in The Verbless Clause in Biblical Hebrew: Linguistic Approaches. Edited by Cynthia L. Miller. LSAWS 1. Winona Lake, IN: Eisenbrauns, 1999.

Nat, Jan. Oefeningen bij de hebreeuwsche grammatica: stukken uit het Oude Testament en woordenlijsten. Revised by J. J. Koopmans. 3rd ed. Leiden: Brill, 1948. 
Naudé, Jacobus A. “A Syntactic Analysis of Dislocation in Biblical Hebrew.” JNSL 16 (1990): 115-30.

. "On Subject Pronoun and Subject Noun Asymmetry: A Preliminary Survey of Northwest Semitic." SAJL 11/1 (1993): 17-28. https://doi.org/10.1080/10118 063.1993.9724323

. "Aspects of the Verbless Clause in Biblical Aramaic." SAJL 11 (1993): 49-

63. https://doi.org/10.1080/10118063.1993.9724489

. "The Verbless Clause with Pleonastic Pronoun in Biblical Aramaic." JSem 6 (1994): 74-93.

. "Holiness in the Dead Sea Scrolls." Pages 171-99 in The Dead Sea Scrolls after Fifty Years: A Reappraisal. Edited by Peter Flint and James C. VanderKam. Leiden: Brill, 1999.

. Review of Word-Order Variation in Isaiah 40-55: A Functional Perspective, by Michael Rosenbaum. OTE 12/1 (1999): 216-18.

. "Syntactic Aspects of Co-Ordinate Subjects with Independent Personal Pronouns." JNSL 25/2 (1999): 75-99.

. "The Third Person Pronoun in Tripartite Verbless Clauses of Qumran Hebrew." Pages 161-82 in Pronouns: Representation and Grammar. Edited by H. J. Simon and H. Wiese. Amsterdam: Benjamins, 2002. https://doi.org/10. 1075/la.52.11nau

. "The Transitions of Biblical Hebrew in the Perspective of Language Change and Diffusion." Pages 189-215 in Biblical Hebrew: Chronology and Typology. Edited by Ian Young. JSOTSupp 369. Sheffield: Sheffield Academic Press, 2003. . Review of On Nature and Language, by Noam Chomsky. SALALS 24/1 (2006): 125-27.

. "Diachrony in Biblical Hebrew and a Theory of Language Change and Diffusion." Pages 61-81 in Diachrony in Biblical Hebrew. Edited by Cynthia L. Miller-Naudé and Ziony Zevit. Winona Lake, IN: Eisenbrauns, 2012. . "Government and Binding." Pages 72-76 in vol. 2 of Encyclopedia of Hebrew Language and Linguistics. Edited by Geoffrey Khan. Leiden: Brill, 2013.

Naudé, Jacobus A. and Cynthia L. Miller-Naudé. "A New Biblical Hebrew Teaching Grammar for African Bible Translators: A Typological Approach.” OTE 24/3 (2011): 690-707.

. "At the Interface of Syntax and Prosody: Differentiating Left Dislocated and

Tripartite Verbless Clauses in Biblical Hebrew." SPL 48 (2017): 223-38.

Nida, Eugene A. Signs, Sense, Translation. Pretoria: University of Pretoria, 1981.

Nida, Eugene A. and Charles R. Taber. The Theory and Practice of Translation. HTrans 8. Leiden: Brill, 1969.

Pike, Kenneth L. Language in Relation to a Unified Theory of the Structure of Human Behaviour. 2nd rev. ed. The Hague: Mouton, 1967.

Pollock, Sheldon. "Introduction." Pages 1-24 in World Philology. Edited by Sheldon Pollock, Benjamin A. Elman, and Ku-ming Kevin Chang. Cambridge, MA: Harvard University Press, 2015. https://doi.org/10.4159/harvard.9780674761 22.intro

Rezetko, Robert and Ian Young. Historical Linguistics and Biblical Hebrew: Steps towards an Integrated Approach. Atlanta: SBL, 2014. https://doi.org/10.2307/ j.ctt14bs6gc 
Richter, Wolfgang. Das Wort. Vol. 1 of Grundlagen einer althebräischen Grammatik. ATSAT 8. St. Ottilien: EOS Verlag, 1978.

. Die Wortfügung (Morphosyntax). Vol. 2 of Grundlagen einer althebräischen Grammatik. ATSAT 10. St. Ottilien: EOS Verlag, 1979.

. Der Satz. Vol. 3 of Grundlagen einer althebräischen Grammatik. ATSAT

13. St. Ottilien: EOS Verlag, 1980.

Robins, Robert H. A Short History of Linguistics. 4th ed. London: Longmans, 1997.

Rosenbaum, Michael. Word-Order Variation in Isaiah 40-55: A Functional Perspective. SSN 35. Assen: Van Gorcum, 1997.

Sampson, Geoffrey, David Gil, and Peter Trudgill. Language Complexity as an Evolving Variable. Oxford: Oxford University Press, 2009.

Snyman, F. P. J. The Scope of the Negative Lo' in Biblical Hebrew. AAcSup. Bloemfontein: UV-Sasol-Biblioteek, 2004.

Turner, James. Philology: The Forgotten Origins of the Modern Humanities. Princeton: Princeton University Press, 2014.

Ungnad, Arthur. Hebräische Grammatik. HHU 1. Tübingen: J.C.B. Mohr [Paul Siebeck], 1912.

Van der Merwe, Christo H. J. "Recent Trends in the Linguistic Description of Old Hebrew." JNSL 15 (1989): 217-41.

. The Old Hebrew Particle gam: A Syntactic-Semantic Description of gam in Gn-2Kg. ATSAT 34. St Ottilien: EOS Verlag, 1990.

. "The Function of Word Order in Old Hebrew - With Special Reference to Cases where a Syntagmeme Precedes a Verb in Joshua." JNSL 17 (1993): 12944.

. "Explaining Fronting in Biblical Hebrew." JNSL 17 (1999): 173-86.

"Some Recent Trends in Biblical Hebrew Linguistics: A Few Pointers towards a More Comprehensive Model of Language Use." HS 44 (2003): 7-24.

. "A Cognitive Linguistic Perspective on הנה in the Pentateuch, Joshua, Judges, and Ruth." HS 48 (2007): 101-40.

. "Another Look at the Biblical Hebrew Focus Particle גם." JSS 14/2 (2009): 313-32

Van der Merwe, Christo H. J. and Alexander Andrason. "Finite Infinite? 'Finite' Uses of the Biblical Hebrew Infinitive Absolute and their Rationale." JSS 59/1 (2014): 255-96. https://doi.org/10.1093/jss/fgu001

Van der Merwe, Christo H. J., Jacobus A. Naudé, and Jan H. Kroeze. 'n BybelsHebreeuse Naslaangrammatika. Kaapstad: Nasionale Boekdrukkerye-Groep, 1997.

Biblical Hebrew Reference Grammar. BibLH 3. Sheffield: Sheffield Academic Press, 1999; 2nd ed. London: Bloomsbury, 2017.

VanGemeren, Willem, ed. New International Dictionary of Old Testament Theology and Exegesis. Grand Rapids: Zondervan, 1976.

Waltke, Bruce K. and Michael O'Connor. Introduction to Biblical Hebrew Syntax. Winona Lake, IN: Eisenbrauns, 1990.

Weingreen, Jacob. Practical Grammar for Classical Hebrew. 2nd ed. Oxford: Oxford University Press, 1959.

Whorf, Benjamin L. Language, Thought and Reality: Selected Papers. New York: Wiley, 1956. 
Naudé \& Miller-Naudé, "BH Linguistics,” OTE 31/1 (2018): 12-41 41

Winther-Nielsen, Nicolai. A Functional Discourse Grammar of Joshua: A ComputerAssisted Rhetorical Structure Analysis. Stockholm: Almqvist \& Wiksell, 1995.

Young, Ian. Robert Rezetko, and Martin Ehrensvärd. The Linguistic Dating of Biblical Texts. London: Equinox, 2008.

Zewi, Tamar. "Subordinate Sentences Involving Prolepsis in Biblical Hebrew." JSS 41 (1996): 1-20.

. "The Definition of the Copula and the Role of 3rd Independent Personal Pronouns in Nominal Sentences of Semitic Languages." FLH 17/1-2 (1996): 4155. https://doi.org/10.1515/flih.1996.17.1-2.41 " "Tripartite Nominal Clauses and Appositional Clauses in Biblical Hebrew." ANES 36 (1999): 36-47. https://doi.org/10.2143/ANES.36.0.525779

. "Is There a Tripartite Nominal Sentence in Biblical Hebrew?" JNSL 26/2 (2000): 51-63.

Zewi, Tamar and Christo H. J. van der Merwe. "Biblical Hebrew Nominal Clause: Definitions of Subject and Predicate." JNSL 27/1 (2001): 81-99.

Jacobus A. Naudé, Department of Hebrew, University of the Free State, Bloemfontein, naudej@ufs.ac.za; ORCID ID: https://orcid.org/0000-0002$\underline{8680-0476}$

Cynthia L. Miller-Naudé, Department of Hebrew, University of the Free State, Bloemfontein, millercl@ufs.ac.za;_ORCID ID: https://orcid.org/0000-00025299-9237. 